\title{
AN ANALYSIS OF STOCK MARKET INTEGRATION IN THE ASIAN DEVELOPED AND EMERGING MARKETS
}

\author{
Sadiq Rehman $^{1 *}$, Asif Ali Abro ${ }^{2}$, Ahmed Raza UI Mustafa ${ }^{3}$, Najeeb Ullah ${ }^{4}$, Sanam Wagma Khattak ${ }^{5}$ \\ ${ }^{1 *}$ MS, Management Sciences Finance, University of Science \&Technology, Bannu, Pakistan; ${ }^{2}$ Head of Special Studies \& \\ Performance Audit Cell, Director General Audit, LCS Karachi, Sindh, Pakistan; ${ }^{3}$ Assistant Professor, Department of \\ Economics, Shaheed Benazir Bhutto University, Shaheed Benazirabad, Pakistan; ${ }^{4}$ Lecturer Management Sciences \\ Finance University of Science \&Technology Bannu, Pakistan; ${ }^{5}$ Department of Economics University of Peshawar, \\ Peshawar, Pakistan. \\ Email: ${ }^{1 *}$ sadiqwazir90@ gmail.com, ${ }^{2}$ aliasifabro15@ gmail.com, ${ }^{3}$ ahmedrazamustafa@ sbbusba.edu.pk, \\ 4unajeeb99@gmail.com, 5 sanamah@uop.edu.pk
}

Article History: Received on $16^{\text {th }}$ June 2021, Revised on $22^{\text {nd }}$ June 2021, Published on $24^{\text {th }}$ June 2021

\section{Abstract}

Purpose of the study: This study investigates Short-run, Long-run, and Casual relationships in the Asian Developed and Emerging stock market indices for the period of 19 years weekly data of stock market indices of Asian Developed and Emerging Markets which are Japan (Nikkei 225), South Korea (KOSPI), Pakistan (KSE 100), China (SSE Composite), Sri Lanka (ASPI), India (BSE 200) and Malaysia (KLSE composite) from January 2001 to December 2019.

Methodology: To analyze long-run and short-run relationships among the Asian developed and emerging stock markets, this study practices Descriptive Statistics, Correlation Matrix, Unit Root Test, Johansen Co-Integration Test, Vector Error Correction Model, Granger Causality test, Variance Decomposition and Impulse Response Function (IRF).

Main findings: By employing the ADF and P.P. tests, the results specify that the entire variables' data are non-stationary and stationary in exact order, which is $1^{\text {st }}$ difference. The Johnson Co-integration test found one cointegration relationship, where the results are consistent with Granger causality, Variance Decomposition, and Impulse Response Function (IRF).

Application of the study: As the current research has focused on finding out the comovements in the Asian developed and emerging markets. So, the applications are that the survey found short-run and long-run relationships in these countries' stock markets.

The study's originality: The current study has selected seven Asian developed and emerging stock markets and weekly updated time series data to investigate short-term and long-term linkages. So, this study found long-run comovements in these stock indices, which contributes to the literature. In addition, these stock markets have limited diversification benefits for international investors, while short-term diversification benefits may exist.

Keywords: Emerging Markets, Developed Markets, Co-integration Test, Granger Causality Test.

\section{INTRODUCTION}

The liberalization globally leads the international markets to integration among them, Rodriguez and Rodrik (2011). Researchers defined the market integration that the linkages or comovements existing in all over the world markets economies are integration in those economies, Forbes and Rigobon (2012). Further research studies indicated that when different markets are integrated, how much risk these markets will have there would have the same level of return (Errunza and Losq (1985). Researchers examined that international financial integration encourages economic growth, which concludes that the research does not support the logic that international financial integration stimulated economic growth (Edison et al. (, 2012). Due to increased integration in world economies, it is perceived rapid increase in global capital mobility from direct or indirect investment (Chen et al. (2016). Financial integration is the cause of abolishing capital flows, foreign exchange transaction, technological advancement, flows of information, and the financial transaction became more accessible among the international countries (Arshanapalli and Doukas, 1993; Khan, Khan, Ullah, Usman, Farhat, 2020). Chan et al. (1997) scrutinized the stock markets integration internationally, examined relationships among eighteen nations, and found no long-run cointegration among the countries, showing diversification benefits. Chen et al. (2012) investigated the behaviour of stock prices in six major Latin American stock exchanges ${ }^{1}$. The researchers found a long-run relationship, which concluded that diversification was of fewer benefits.

This study is also based on this approach, which examines the Long-run, Short-run, and Casual relationship in the Asian developed and emerging stock markets. Asian developed markets are Japan and South Korea, and Asian emerging markets are Pakistan, China, Sri Lanka, India, and Malaysia under World Bank criteria ${ }^{2}$. This study identifies the relationship among the stock indices of Japan (Nikkei 225), South Korea (KOSPI 200), Pakistan (KSE 100), China (SSE Composite), Sri Lanka (CSE), India (BSE 200), and Malaysia (KLSE Composite) by using weekly stock price indices

\footnotetext{
${ }^{1}$ Argentina, Brazil, Chile, Colombia, Mexico and Venezuela.

${ }^{2}$ Classification of Countries is from the World Bank, July 2012, on the basis of 2011 GNI per capita.
} 
from January 2001 to December 2019. The study is employing Cointegration tests, and Granger Causality tests to investigate short-run and long-run relationships.

\section{Karachi stock exchange}

Karachi Stock Exchange (KSE) is the biggest stock exchange in Pakistan. It was recognized on September 181947 and started operation on March 10, 1949. The first index introduced was KSE 50, on which fifty companies were registered. When the numbers of listed companies and trading activities increased, there was a need for a good representative index. Therefore, KSE 100 index was introduced on November 1, 1991, with a base value of 1000 points. Total listed companies on KSE 100 index are 579 from 36 different sectors. The listing on KSE is done according to the rules and regulations of the Security and Exchange Commotion of Pakistan. SECP, (www.kse.com.pk).

\section{Shanghai Stock Exchange}

In 1860, stocks trading were started in Shanghai. Share broker association was recognized in 1891 in Shanghai. Shanghai Security Goods Exchange and Shanghai Chinese Security Exchange came into being and started operations correspondingly in 1921. Shanghai Security Company Ltd was founded in 1946 on the Chinese Security Exchange, which stopped operations in 1949. Later on, trading in treasury bonds recommenced in 1981. Shanghai and some other big cities had emerged stocks and enterprise bonds in 1984. Then Shanghai Stock Exchange came into being on November 261990 and started formal operation on December 19, 1990. There are 1081 listed companies on Shanghai Stock Exchange (SSE) (english.sse.org.cn).

\section{Colombo Stock Exchange}

In Sri Lanka, a Share Broker Association (SBA) was first introduced for share trading in1896. Later in 1904, the association was renamed Colombo Broker Association (CBA) and started trading on open land. After some time, Stock Broker Association emerged. As a result, both the associations merged; Colombo Security Exchange (CSE) was introduced in 1985. Later on, in the same year, in 1985, a formal stock exchange was established and was named (CSE). In 1995, CSE opened its headquarters at World Trade Center WTC Colombo. The listed companies on CSE are 295, and market capitalization is the U.S. $\$ 18.5$ billion (https://www.cse.lk).

\section{Bombay Stock Exchange}

Bombay Stock Exchange (BSE) is a stock exchange of India. The BSE is located at Dalal Street, Kala Ghoda, Mumbai, and Maharashtra, India. This stock exchange was established in 1875. BSE is the fastest stock exchange in the Asian region and the oldest stock exchange in the South Asian province. BSE is the $11^{\text {th }}$ World's largest stock market based on a market capitalization of $\$ 1.7$ trillion. Companies listed on BSE are more than 5000 (www.bseindia.com).

\section{Kula Lumper Stock Exchange}

Kula Lumper Stock Exchange was formed when the Singapore Brokers Association was dealt with as a formal organization in Malaysia in 1930. The association was registered as the Malaysian Brokers Association in 1937 but could not trade public securities. In 1960, the Malaysian Stock Exchange was introduced, divided into two sections on Kula Lumper and second in Singapore, which was communicated through telephones. As a result, the Stock Exchange of Malaysia was shaped in 1964 officially, and Singapore was separated. The Malaysian Stock Exchange was renamed as Kula Lumper Stock Exchange (KLSE) in 1994. In 2004 the KLSE was renamed Bursa Malaysia, with a total capital of US $\$ 189$ billion. Totally 813 companies are listed on this stock exchange (www.malaysiastock.biz).

\section{Tokyo Stock Exchange (Nikkei 225)}

Tokyo Stock Exchange (TSE) is located in Tokyo, Japan. TSE is the fourth position in the capital in the world, with a market capitalization of US\$4.09 trillion. Total listed companies on TSE are 2292. There are three sections. The first section contains large companies, the second mid-size companies, and the last Quarter is emerging stock markets. Listed companies for each section are 1675, 437, and 182 consistently. The Nikkei 225 index of TSE is the top stock index of TSE based on stocks of the first section companies (www.tse.or.jp/english).

\section{Korean Composite Stock Price Index}

Korea Composite Stock Price Index (KOSPI) is the South Korean Stock Index where all the common stocks are traded. It was introduced in 1983 with a base value of 100 points. It is an index of the Korean Stock Exchange. All the South Korean Stocks are traded and indicated on KOSPI. Listed companies on the Korean Stock exchange are 1800, and South Korean companies listed on KOSPI are 200. From 1989, 1984 till 2000, the base value of KOSPI was 1000. During 9/11, the KOSPI dropped $12.02 \%$ (https://global.krx.co.kr).

\section{Objectives of the study}

1. The objective of this study is to find short-run associations in the Asian Developed and emerging stock markets.

2. The study is based on finding out long-run comovements in the Asian Stock markets indices. 
3. Further, the study examined the causal relationship in the Asian developed and emerging stock markets.

\section{LITERATURE REVIEW}

Based on different researchers, they have found long-run, short-run associations. Some others found short-run and longrun diversification benefits in the developed and emerging countries of the world. However, due to liberalization, the global markets become integrated, diminishing diversification benefits for international investors (Gilmore and McManus, 2012; Shaikh, Channar, \& Shaikh, Ullah, (2021). Therefore, the present study divided the literature into two sections as under.

Section1- The article where the researcher found positive relationships among the international stock markets, Arshanapalli and Doukkas (1993) found long-run associations in world markets of UK, Germany, and France with U.S. Meric and Gulser (1997). They found a long-run relationship in European stock markets, Arshanapalli and Doukkas (1993). Masih and Masih (1999) investigated the relationships between U.S. and U.K. The researcher found long-run and short-run associations of the developed countries with almost all Asian countries, i.e. Singapore, Malaysia, Hong Kong, and Thailand. The author found a long-run association in these stock markets indices, while a short-run relationship was not found. Moon (2016) found the associations of the U.S. with East Asian stock markets, i.e. Japan, Taiwan, Philippines, Hong Kong, Indonesia, Thailand, Singapore, Malaysia, and Korea in the long run as well in the short run, Masih and Masih (1999). Chen et al. (2012) found long-run associations in Latin American Stock markets, i.e. Argentina, Brazil, Chile, Colombia, Mexico, and Venezuela, while no any Short-run relationship was found. Garrett et al. (2014) found the associations of U.S. stocks with Latin American Stocks, i.e. Chile, Columbia, Mexico, Argentina, Brazil, Chile, and Venezuela, in the long run (Meric and Gulser, 1997; Ullah, Shaikh, Channar, \& Shaikh, 2021). Wong et al. (2014) examined integration relationships of the Indian markets with the major stock markets of developed countries, i.e. the U.K., the U.S., and Japan. The final findings indicated a short-run and long-run relationship of the Indian markets with the developed countries' stock markets under investigation and the further strong influence of developed markets on India. Click and Plummer (2015) examined the comovements of Asian stock markets, i.e. Malaysia, Singapore, Philippines, Indonesia, and Thailand. The researcher found limited diversification benefits in the Pacific Asian countries, Wong et al. (2004). Chen et al. (2016) found who were found cointegration associations in the three pairs, i.e. India-US, India-China, and China-US. Sulaiman D. Mohammad (2017) Ullah, Malik, Zeb, Rehman, $\underline{(2019)}$ found long-run linkages of Pakistani equity markets with American equity markets. Khan et al. (2014) found long-run comovements of Pakistani stock market with Asian stock markets. Chen et al. (2012) and Jawadi \& Arouri (2008) found short-run and long-run associations of the French stock market indices (Paris stock index) with the U.S. (NYSE index). Searat et al. (2011) found a long-run equilibrium relationship of Pakistani equity markets with other Asian countries of India, China, Japan, and Indonesia. Palamalai et al. (2013) examined the short-run, long-run, and causal association ships in the emerging Asian Pacific countries stock markets, i.e. South Korea, Taiwan, Japan, China, Indonesia, India, Malaysia, Hong Kong, Singapore, U.S., and the U.K. and found long-run comovements in this region.

Section -2 Researchers had found benefits from portfolio diversification; Lessard (1973) found diversification benefits in Latin American countries of Chile, Colombia, Argentina, and Brazil. Gilmore and McManus (2012) investigated the short-run and long-run relationship between U.S. stock markets and three Central European markets of the Czech Republic, Hungary, and Poland. The findings indicated that there was no long-run association ship between the U.S. and the three European countries. Garrett et al. (2014) found no long-run relationship between Latin American and U.S. stock market indices (Gilmore and McManus (2012). Canarella et al. (2019) investigated the dynamic and long-run linkages in the US, Canada, and Mexico stock markets and found no long-run associations in these stock markets. Gurcharan and Pritam (2019) examined the relationships of India and China, which were leading emerging markets with developed markets which were the U.S., UK, Hong Kong, and Japan, and found no long-run associations. Gupta and Agarwal (2011) examined the stock market linkages of Indian stock markets with major Asian stock markets, i.e. Hong Kong, Indonesia, Malaysia, Japan, and Korea. The indications were that the study found a weak correlation of Indian stock indexes with other Asian countries under investigation. Iqbal et al. (2011) examined the dynamic linkages in the Pakistani and Indian stock markets with the U.S. stock markets and found no long-run associations (Gurcharan and Pritam (2018). Bhunia \& Das (2012) researched the stock market integration in the Indian stock markets and South Asian stock markets, i.e. China, South Korea, Taiwan, Hong Kong, Indonesia, Malaysia, Japan, and Singapore. The indications of the study concluded that the Indian Stock markets and the South Asian stock markets had benefits of diversification in the long run while short-run services may not exist. Tabak \& Lima (2013) conducted a research study to analyze causality and cointegration relationships among stock markets for Argentina, Brazil, Columbia, Mexico, Peru, Venezuela, and the U.S. The researchers found no cointegration between Latin America and Latin America with the US, Lessard (1973); Garrett et al. (2014).

It is concluded from the above literature that the stock markets having associations with each other have no diversification benefits, while the stock markets having no relationships obtain diversification benefits for investors in the globe.

\section{DATA AND METHODOLOGY}

Universe of the Study 
The study is based on time series data of Asian Developed and Emerging stock markets. The sample size is based on 19 years of weekly data of Asian developed and emerging markets. The needs investigated are China (SSE Composite), India (BSE 200), Japan (Nikkei 225), Malaysia (KLSE composite), Pakistan (KSE 100), South Korea (KOSPI), and Sri Lanka (ASPI) from 2001 to 2019. The study is based on secondary data. The sample consists of the Asian developed and emerging countries for which sufficiently long series of weekly data is available. The information has been abstracted from various sources ${ }^{3}$.

\section{Variables of the Study}

The relationship among the developed and emerging stock markets have been analyzed by different researchers such as Chan et al. (1997), Chen et al. (2012), Gilmore and McManus (2002), and Click and Plummer (2015), etc. These countries selected variables both from emerging and developed markets. All of them have used different models and found different results. Due to the particular emphasis on the Asian region, the current study investigates the long-run, short-run, and causal relationship among the Asian developed and emerging stock markets. The present study investigates the association among two Asian developed stock markets of Japan and South Korea and five emerging stock markets of Pakistan, China, Sri Lanka, India, and Malaysia. The study analyzes the long-run, short-run, and causal relationship among the stock as mentioned above market indices of Japan (Nikkei 225), South Korea (KOSPI), Malaysia (KLSE), Pakistan (KSE 100), China (SSE), Sri Lanka (CSE), and India (BSE).

\section{Estimation Tools}

To investigate the relationships in the Asian developed and emerging stock markets, the current study employed descriptive statistics, correlation matrix, Unit Root Tests, Johansen Co-Integration Test, Vector Error Correction Model (VECM), Granger Causality test, Variance Decomposition, and Impulse Response Function (IRF). This methodology is followed by various existing studies such as Canarella et al. (2018), Gurcharan and Pritam (2010).

\section{Descriptive Statistics}

The Descriptive Statistics brought to scrutinize the behaviour of the data using for further analysis. The descriptive Statistics comprises mean, median, maximum, minimum, standard deviation, skewness, and kurtosis. The average return of each stock market and standard deviation measure how much risk is in each stock market of the study. Skewness measures that the data is either positively or negatively skewed, which tells the symmetry of the data. Kurtosis shows that the information is either normally distributed or not.

\section{Correlation Matrix}

The Correlation Matrix is used to examine the association in the variables. This is also used to identify that the variables are positively or negatively correlated (Canarella et al. (, 2018). The drawback of this tool is it is only used to examine the relationship between the variables but cannot investigate that the variables have short-run or long-run relationships. For example, the correlation between the two stock markets may be positive or negative. When the two variables are highly correlated, the co-efficient value maybe +1 or -1 . The positive relationship shows, when one variable return increases, the other return will also increase, and the antagonistic relationship shows that one variable return increases, the other will decrease. The co-efficient value near zero implies no ties.

\section{Unit Root Test}

The Unit Root Tests are used to investigate that the data is either stationary or non-stationary. This is important because if the information is static in the same order, cointegration tests will be employed. The cointegration assumption is that the data must be stationary at the same level. This study practices Augmented Dicky Fuller (ADF) and Philips Peron Test (P.P.) to identify the fact that the data is stationary in the same order. The ADF assumption is that the error term variance is constant, and the error term is the independent variable. P.P. is a generalized form of ADF. The models for $\mathrm{ADF}$ and P.P. are as under,

\section{Augmented Dickey-Fuller (ADF)}

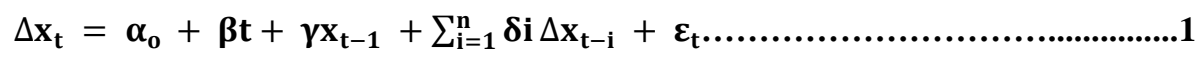

Where

$\mathrm{t}=$ time index $\mathrm{x}_{\mathrm{t}}=$ variable in period " $\mathrm{t} " \alpha_{\mathrm{o}}=$ intercept constant called drift

$\beta=$ coefficient on-time trend $\gamma=$ coefficient presenting process root $\delta=$ lag order of the first difference $\varepsilon_{\mathrm{t}}=$ an independent identically distributes residual term.

\section{Phillip Perron (P.P.)}

\footnotetext{
${ }^{3}$ Sources are Yahoo Finance and each country stock exchange i.e. Bombay stock exchange, Colombo stock exchange, Karachi stock exchange, Kula Lumper stock exchange, Tokyo stock exchange, Shanghai stock exchange and South Korean stock exchange.
} 


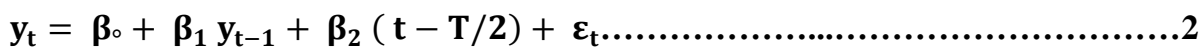

Where

$\mathrm{y}_{\mathrm{t}}=$ variable in period "t" $\beta_{\mathrm{o}}=$ intercept $\beta_{1}$ and $\beta_{2}=$ coefficient

$\mathrm{T}=$ number of observations $\varepsilon_{\mathrm{t}}=$ disturbance term

The series is non-stationary is the null hypothesis of both the ADF test and P.P. test.

Where,

Ho: $\varnothing=0, \rho=1$ and H1: $\varnothing<1, \rho<1$

\section{Johansen Co-Integration Test}

To examine the long-run relationship among the Asian developed and emerging stock markets, this study practices the Johansen cointegration test (1988). The Johansen cointegration test (1988) now removed the limitation of the EngleGranger methodology. Engle granger is two steps procedure where one step shows a relationship and the other shows no relationship. Johansen's cointegration test (1988) is based on two tests Trace test and the Maximum Eigen Value test. This technique will investigate whether there are any long-run relationships among the variables when the Johansen test found at least one cointegration relationship. To investigate long-run and short-run associations among the time series variables, Vector Error Correction Model will be employed (VECM). The Johansen Co-integration test is started from Vector Auto-regression (VAR). Thus, VAR can be modelled as:

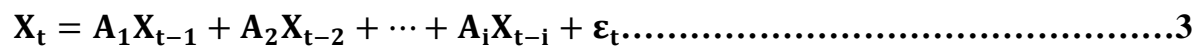

It can be rewritten as:

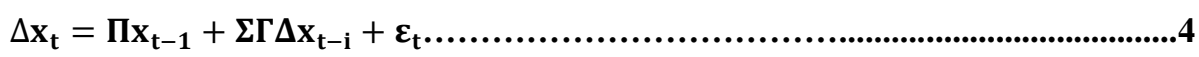

Where,

$\Pi=\Sigma \mathrm{A}_{\mathrm{i}}-\mathrm{I}$

$\Gamma_{\mathrm{i}}=-\Sigma \mathrm{A}_{\mathrm{i}}$

The matrix $\Pi$ has the rank $r$ by which it determines the presence of co-integrating vectors. This study investigates the long-run relationship among seven stock markets, where seven co-integrating vectors are possible in the time series variables of the study.

The Johansen cointegration test based on two tests, one is Trace test, and the second is the Maximum Eigenvalue test, which is modelling as,

\section{Trace test}

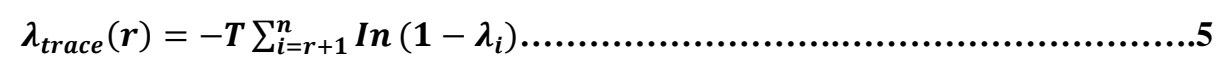

Where

$\mathrm{r}=$ number of co-integrating vectors $\ln =$ natural $\log$

$\lambda_{\mathrm{i}}=$ estimated value for the ith ordered eigenvalue

Where the null hypothesis is;

Ho: number of cointegration vector $\leq \mathrm{r}$

Another test is the Maximum Eigenvalue test that can be expressed as:

\section{Maximum Eigen Value test}

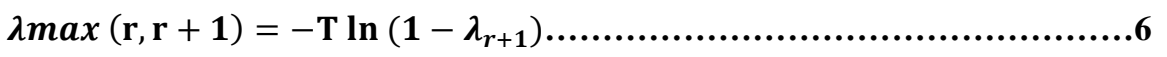

Where Ho: number of cointegration relationship $=r$

\section{Vector Error Correction Model (VECM)}

The research study used Vector Error Correction Model (VECM) to conform the long-run and short-run relationship amongst the time series variables, Moon (2018), Chen et al. (2015), Gilmore and McManus (2012). The model for VECM is as under,

$$
\Delta Y_{t}=\Pi Y_{t-k}+\Gamma_{1} \Delta Y_{t-1}+\Gamma_{2} \Delta Y_{t-2}+\cdots \ldots \ldots \ldots+\Gamma_{k-1} \Delta Y_{t-(k-1)}+\varepsilon_{t} \ldots \ldots \ldots \ldots . .7
$$

Where

$\Gamma_{i}=\left(\sum_{j=1}^{i} \beta_{j}\right)-I_{g}$ 
" $\Gamma$ " is the Metrix used for the representation of short-run relationship and $\beta_{j}$ Is the matrix of the short-run coefficients.

$\Pi=\left(\sum_{i=1}^{k} \beta_{i}\right)-I_{g}$ . .7 .2$

" $\Pi "$ Is the Metrix used for the long-run relationship and $\beta_{i}$ Is the matrix of the long-run coefficients that represents up to g-1 co-integrating relationship.

\section{Granger Causality Test}

The Granger Causality Test is employed to examine the causal relationships between the variables of the research study. The time series variables of the research might be unidirectional or bidirectional relationships with each other, Chen et al. (2002). Gilmore and McManus (2012), Gurcharan and Pritam (2016). This test is used to examine the lead and lag relationship, which is bidirectional and unidirectional, one stock market influence on others. The model is given as under,

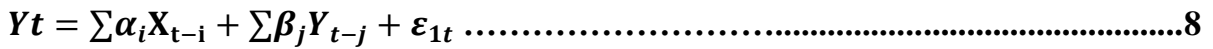

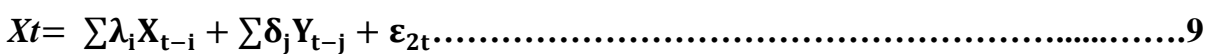

Where

$\mathbf{Y}_{\mathbf{t}}$ and $\mathbf{X}_{\mathbf{t}}=$ stationary variables $\boldsymbol{\varepsilon}_{\mathbf{1 t}}$ and $\boldsymbol{\varepsilon}_{\mathbf{2 t}}=$ uncorrelated white noises series

\section{Variance Decomposition}

The Variance Decomposition is employed to examine how many variances in a stock market are due to its variation and how many disagreements are due to the innovation of other developed and emerging stock markets counterparts (Moon (2001). It demonstrates the Variance Decomposition for the individual stock market of advanced and emerging economies of the research study. The research study used Variance Decomposition analysis to examine the dynamic changes in the stock markets of the study, which identify that either the dynamic changes in the stock markets are due to their innovations or due to other stock markets.

\section{Impulse Response Function}

The impulse response function is applied to check out the response of the dependent variable to the dynamic changes of each variable under study. Thus, there is an equation separately for each variable. The effects over time can watch out under the impulse response function. If there are "s" variables, so it could be generated." $s^{2}$ impulse responses. To analyze the effects of shocks, we first estimate VAR. So VAR can be written as:

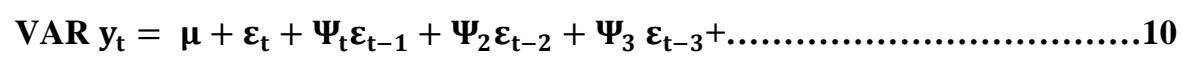

Where

$\Psi_{s}=\frac{\partial y_{t+s}}{\partial \varepsilon_{t}}$ It is called the Impulse Response Function (IRF).

When one standard deviation shock is bringing in the variable on the period " $t$ ", then $\Psi_{s}$ identifies the consequences of this innovation.

\section{RESULTS AND DISCUSSION}

\section{Descriptive Statistics}

Table 1 summarizes several descriptive statistics for the countries' stock markets under investigation. In the table, the Mean comprises the average weekly return, maximum and minimum indicates maximum and minimum weekly return, standard deviation specifies the risk, and the skewness suggest that the data is either positively or negatively skewed. Therefore, the countries stock markets having higher average weekly return and the low standard deviation is fruitful for investments. Here in this table, Sri Lanka (CSE) displays the highest maximum return of $17.9 \%$ and a low risk of $2.8 \%$. Secondly, South Korea (KOSPI) has a high maximum return of 17\%, and risk is $3.3 \%$. Malaysia (KLSE) has the lowest maximum return of $6.7 \%$, with the lowest risk of $1.9 \%$. The countries India (BSE) have the maximum weekly return of 13.2\%, China (SSE) 11.7\%, remaining and Japan (N225) 11.4\% and Pakistan 10.9\% respectively. The stock indices understudy all the stock indices are negatively skewed except Japan (Nikkei 225) stock index and China (SSE), which indicates that the countries' weekly returns under study were negative in more weeks than positive except Japan and China stock markets. The Jarque-Bera suggests that the data is not normally distributed. The kurtoses measure shows that the data is leptokurtic, where the values of all the sample variables are more significant than 3 , which concluded that the information is non-normally distributed.

Table 1: Summary statistics of the weekly returns of each developed and emerging market

\begin{tabular}{cccccccc}
\hline & BSE & CSE & KLSE & KOSPI & KSE & N225 & SSE \\
\hline Mean & 0.002 & 0.004 & 0.002 & 0.002 & 0.004 & 0.001 & 0.001 \\
\hline
\end{tabular}


https://doi.org/10.18510/hssr.2021.93116

\begin{tabular}{cccccccc}
\hline Max & 0.132 & 0.179 & 0.067 & 0.170 & 0.109 & 0.114 & 0.117 \\
\hline Min & -0.174 & -0.113 & -0.114 & -0.229 & -0.201 & -0.278 & -0.178 \\
\hline Std. Dev. & 0.032 & 0.028 & 0.019 & 0.033 & 0.033 & 0.031 & 0.031 \\
\hline Skewness & -0.503 & 0.648 & -0.818 & -0.665 & -1.274 & -1.132 & -0.246 \\
\hline Kurtosis & 5.855 & 8.085 & 7.578 & 8.139 & 8.335 & 11.68 & 5.797 \\
\hline $\begin{array}{c}\text { Jarque- } \\
\text { Bera }\end{array}$ & $278.8^{*}$ & $837.9^{*}$ & $719.0^{*}$ & $857.2^{*}$ & $1063.3^{*}$ & $2447.5^{*}$ & $245.3^{*}$ \\
\hline $\mathrm{N}$ & 870 & 870 & 870 & 870 & 870 & 870 & 870 \\
\hline
\end{tabular}

Notes: The table contains the descriptive data for the Asian developed and emerging stock markets. The Mean is the weekly average return, Max, Min and Std, Dev, denoted maximum, minimum weekly return, and standard deviation. Skewness indicates that either the data is negatively or positively skewed. (*) suggests that the Jarque-Bera stats are significant at a 5 percent level, and $(\mathrm{N})$ is the numbers of observations.

\section{Correlation Matrix}

The research study employed a correlation matrix to identify the relationship in the Asian Developed and Emerging Stock market indices. The correlation between the two stock markets may be positive or negative. When the two variables are highly correlated, the co-efficient value maybe +1 or -1 . The positive relationship shows, when one variable return increases, the other return will also increase, and the antagonistic relationship shows that one variable return increases, the other will decrease. The co-efficient value near zero implies no ties. Table 2 reports the most vital relationship between China and South Korea, which correlation coefficient value is near 1. Further, the research found an association between Chinese and Indian stock returns and

between Indian and South Korean stock returns. Japan have no relationship with any developed and emerging stock index of the sample. As the previous studies argued, the developed markets have low relationships with emerging markets (Gilmore and McManus (2012), Chen et al. (2012). The correlation matrix has the limitation that it cannot tell us about the short-run and long-run relationships. It only identifies the correlations among the stock market returns, Jebran (2014), Shezad et al. (2014). Therefore, the study will employ cointegration to investigate the long-run relationship, Chan et al. (1997), Masih \& Masih (1999), Chen et al. (2002), Gilmore and McManus (2002), Tabak, \& Lima (2013), etc.

Table 2: displaying the correlation matrix of the seven developed and emerging markets from 2001 to 2019

\begin{tabular}{llllllll}
\hline & BSE & CSE & CLOSE & KOSPI & KSA & N225 & SSE \\
\hline BSE & 1 & & & & & & \\
\hline CSE & $0.19^{*}$ & 1 & & & & & \\
\hline KLSE & $0.09^{*}$ & -0.03 & 1 & & & & \\
\hline KOSPI & $0.52^{*}$ & $0.12^{*}$ & 0.06 & 1 & & \\
\hline KSE & 0.02 & -0.01 & -0.03 & -0.02 & 1 & 1 & 1 \\
\hline N225 & 0.03 & 0.02 & $0.26^{*}$ & -0.02 & -0.02 & 0.02 & \\
\hline SSE & $0.59^{*}$ & $0.17^{*}$ & 0.05 & $0.65^{*}$ & -0.04 & \\
\hline
\end{tabular}

Notes: This table summarizes the correlation coefficients among the Asian Developed and Emerging markets weekly share prices for the period of 19years from 2001-2019. A strong relationship is between China and South Korea.

\section{Unit Root Test}

The research study employed a correlation matrix to investigate the association among the variables. Still, to explore the long-run and short-run relationship, the task is using the cointegration test. The cointegration test assumes that the data must be non-stationary and integrated of the same order, preferably I(1). To clarify the fact that either the data is stationary in the same order or not, this research employs two tests Augmented Ducky Fuller (ADF) and Philips Parron (PP) tests, Moon (2001), Chen et al (2002), Gilmore and McManus (2002), Fernández \& Sosvilla (2002). Table 3 summarizes the results of the Unit Root Tests. By employing the ADF and P.P. tests, the results specify that all the variable's data is non-stationary and stationary in the first difference. The $\left(^{*}\right)$ in the table shows significance at a 5 percent level. So it is clear that we can investigate the long-run relationship by employing the cointegration test.

Table 3: Shows unit root tests result for seven developed and emerging stock markets of Asia

\begin{tabular}{ccccc}
\hline \multicolumn{2}{c}{ Variables Augmented Ducky Fuller } & \multicolumn{2}{c}{ Philips Parron } \\
\hline \multicolumn{2}{c}{ Level } & $1^{\text {st }}$ diff & Level & $1^{\text {st }}$ diff \\
\hline & T Stat & T Stat & T Stat & T Stat \\
\hline CSE & -1.57 & $-12.7^{*}$ & -1.49 & $-23.6^{*}$ \\
\hline BSE & -1.20 & $-6.43^{*}$ & -0.57 & $-26.4^{*}$ \\
\hline KSE & -1.39 & $-11.1^{*}$ & -1.26 & $-23.5^{*}$ \\
\hline
\end{tabular}




\begin{tabular}{ccccc}
\hline KLSE & -0.71 & $-16.9^{*}$ & -0.80 & $-25.1^{*}$ \\
\hline KOSPI & -1.58 & $-29.1^{*}$ & -1.75 & $-29.1^{*}$ \\
\hline N225 & -1.43 & $-15.7^{*}$ & -1.49 & $-27.3^{*}$ \\
\hline SSE & -1.15 & $-18.0^{*}$ & -1.25 & $-27.3^{*}$ \\
\hline
\end{tabular}

Notes: The table comprises two sections, Augmented Dicky Fuller test (ADF) And Philips Peron test (P.P.), to identify that the data is stationary at level or maybe at $1^{\text {st }}$ difference for the eight emerging and developed stock markets. This indicates that the information is stationary at $1^{\text {st }}$ difference from both the tests. $(*)$ indicates significant at $5 \%$ level.

\section{Lag Structure}

This study is examining the long-run and short-run relationship among the variables under study. To identify long-run and short-run relationships, this study employs a cointegration test. To run the Co-integration test lag value is needed. Different researchers used different lag length criteria. By finding the appropriate lag vale, Vector Autoregressive Statistics are using in this study. Table 4 summarizes the lag values, which indicates that this research study will use lag 1 for running the cointegration test which is an appropriate lag value by Schwarz criteria, Shezad et al (2014). Most of the researchers used Akaike Information Criteria (AIC). This study uses S.C. because S.C. is significant at lag 1 and AIC is significant at lag 4 . The results from lag 1 will be accurate instead of lag 4 .

Table 4: Summarizes the Lag structure

\begin{tabular}{lllllll}
\hline Lag & LogL & LR & FPE & AIC & SC & HQ \\
\hline 0 & 2173.4 & NA & 3.46 & -5.99 & -5.93 & -5.97 \\
\hline 1 & 12731.1 & 20852.4 & 8.55 & -35.01 & $-34.5^{*}$ & $34.8^{*}$ \\
\hline 2 & 12814.4 & 162.1 & 8.12 & -35.1 & -34.2 & -34.7 \\
\hline 3 & 12870.6 & 109.1 & 8.28 & -35.1 & -33.7 & -34.5 \\
\hline 4 & 13019.2 & 283.4 & $6.56^{*}$ & $-35.28^{*}$ & -33.6 & -34.6 \\
\hline 5 & 13064.3 & 85.1 & 6.91 & -35.2 & -33.15 & -34.4 \\
\hline 6 & 13115.7 & 95.8 & 7.16 & -35.2 & -32.7 & -34.2 \\
\hline 7 & 13160.3 & 82.2 & 7.56 & -35.2 & -32.2 & -34.1 \\
\hline
\end{tabular}

Notes: This table specifies the Lag Order selected by the Schwarz criterion. Where $(*)$ shows the significant Lag value.

\section{Johansen Co-integration test}

This research study using time series data for analysis. As the results of the ADF and P.P. tests directs that the data is stationary of order 1 e.t. I (1). Now to investigate the long-run relationship among the time series variables Johansen Cointegration test (1988) will employ, Chan et al (1997), Moon (2001), Chen et al (2002), Gilmore and McManus (2002), Click and Plummer (2005), etc. This test is based on two tests Trace test and the Maximum Eigen Value test, Jebran (2014). Table 5 summarized the results for cointegration by using Trace Test and Maximum.

Table 5: Summarizes the result of the Trace test and the Maximum Eigen Value test

\begin{tabular}{lcccc}
\hline Trace test & & & & \\
\hline No. of CE(s) & Eigenvalue & Statistic & Critical Value & Prob.* \\
\hline None $*$ & 0.10 & 201.6 & 159.5 & $0.00^{*}$ \\
\hline At most 1 & 0.06 & 120.4 & 125.6 & 0.09 \\
\hline At most 2 & 0.03 & 74.26 & 95.75 & 0.58 \\
\hline At most 3 & 0.02 & 51.07 & 69.81 & 0.59 \\
\hline At most 4 & 0.02 & 32.37 & 47.85 & 0.59 \\
\hline At most 5 & 0.02 & 17.39 & 29.79 & 0.61 \\
\hline At most 6 & 0.01 & 8.629 & 15.49 & 0.40 \\
\hline
\end{tabular}

\section{Vector Error Correction Model (VECM)}

As the Johnsen Co-integration test found one cointegration relationship among the Asian developed and emerging stock markets of Asia. To investigate the long-run and short-run association among markets Vector Error Correction Model (VECM) will employ. The VECM identifies that either the stock market indices are positively or negatively inter-linked. Table 6 represents the short-term and long-term relationships among the time series variables. This research found a long-run relationship among all the Asian developed and emerging stock market prices. The results indicate that there is a short-run relationship between India and Malaysia, India and China, Pakistan and South Korea. Further, the results show that the research study found the short-run relationship between Malaysia and China, South Korea and India, South Korea and Malaysia, China and Malaysia, Japan, and Sri Lanka. The Sri Lankan stock indices have short-run relationships, which clarify that a one-week previous price effect the current prices. Moon (2001) had found long-run as 
well short-run association among Japan, Malaysia, Indonesia, and South Korea. Click and Plummer (2015) found longrun equilibrium associations in the Asian region.

Table 6: Summarizes short and Long-term relationship in the variables for 2001-2019

\begin{tabular}{llllllll}
\hline ECM & D(KSE) & D(BSE) & D(CSE) & D(KLSE) & D(KOSPI) & D(SSE) & D(N225) \\
\hline ContEq1 & -0.01 & -0.01 & -0.01 & -0.01 & -0.01 & -0.01 & -0.01 \\
\hline & $-2.53^{*}$ & $-4.06^{*}$ & $-2.03^{*}$ & $-5.22^{*}$ & $-4.74^{*}$ & $-5.67^{*}$ & $-3.74^{*}$ \\
\hline $\mathrm{D}(\mathrm{BSE}(-1))$ & 0.02 & -0.09 & -0.00 & 0.01 & 0.10 & 0.09 & 0.04 \\
\hline & 0.46 & -1.89 & -0.04 & 0.26 & $2.18^{*}$ & $1.97^{*}$ & 0.83 \\
\hline $\mathrm{D}(\mathrm{KSE}(-1))$ & 0.14 & 0.05 & 0.01 & 0.01 & 0.00 & -0.05 & 0.03 \\
\hline & $3.80^{*}$ & 1.30 & 0.42 & 0.68 & 0.01 & -1.35 & 0.72 \\
\hline $\mathrm{D}(\mathrm{CSE}(-1))$ & 0.03 & 0.02 & 0.15 & -0.00 & -0.01 & -0.03 & -0.09 \\
\hline & 0.73 & 0.45 & $3.98^{*}$ & -0.02 & -0.30 & -0.75 & $-2.35^{*}$ \\
\hline $\mathrm{D}(\mathrm{KLSE}(1))$ & -0.03 & 0.24 & 0.13 & 0.05 & 0.25 & 0.28 & 0.09 \\
\hline & -0.50 & $3.72^{*}$ & 1.83 & 1.18 & $3.82^{*}$ & $4.58^{*}$ & 1.56 \\
\hline $\mathrm{D}(\mathrm{KOSPI}(1)$ & 0.19 & 0.01 & 0.03 & -0.06 & -0.21 & -0.07 & -0.03 \\
\hline & $3.96^{*}$ & 0.06 & 0.71 & -1.99 & $-4.28^{*}$ & -1.58 & -0.72 \\
\hline $\mathrm{D}(\mathrm{SSE}(-1))$ & -0.05 & 0.15 & -0.03 & 0.07 & 0.11 & -0.04 & 0.03 \\
\hline & -0.95 & $2.86^{*}$ & -0.56 & $2.04 *$ & $1.98^{*}$ & -0.68 & 0.63 \\
\hline $\mathrm{D}(\mathrm{N} 225(-1))$ & 0.02 & 0.04 & 0.02 & 0.04 & -0.01 & -0.01 & -0.06 \\
\hline & 0.34 & 1.08 & 0.37 & 1.14 & -0.13 & -0.08 & -1.49 \\
\hline
\end{tabular}

Notes: The table designates the short-run and long-run relationships among the time series variables of the study for the period of 2001-2019. The $(*)$ indicates the relationship in the time series variables.

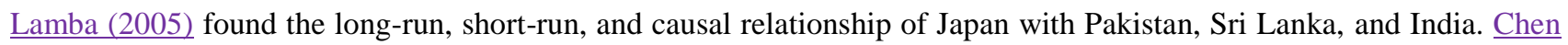
et al. (2006) found long-run and short-run associations between India and China. Meric et al. (1997) were seen limited diversification benefits in Asian countries.

\section{Granger Causality Test}

The research study employed the Granger causality test to examine the unidirectional or bidirectional relationships among the time series variables under examination. The previous studies argued that there might be unidirectional or bidirectional relationships, Chen et al. (2002), Gilmore and McManus (2012), Gurcharan and Pritam (2018). Table 7 summarizes the casual relationship among the time series variables under study. The casual relationship indicates

Table 7: Reports the pairwise granger causal relationship in the time series variables

\begin{tabular}{llll}
\hline F Stat Prob & & F Stat & Prob \\
\hline CSE to BSE 0.610 .43 & KOSPI to KLSE & 0.24 & 0.62 \\
\hline BSE to CSE 0.050 .81 & KLSE to KOSPI & 22.1 & $0.00^{*}$ \\
\hline \hline KLSE to BSE $21.60 .01^{*}$ & KSE to KLSE & 1.50 & 0.21 \\
\hline BSE to KLSE 0.820 .36 & KLSE to KSE & 0.04 & 0.82 \\
\hline \hline KOSPI to BSE 2.83 0.05* & N225 to KLSE & 4.84 & $0.02^{*}$ \\
\hline BSE to KOSPI $12.00 .00^{*}$ & KLSE to N225 & 4.01 & $0.04^{*}$ \\
\hline KSE to BSE 1.130 .14 & SSE to KLSE & 1.61 & 0.10 \\
\hline BSE to KSE 7.66 0.00* & KLSE to SSE & 31.6 & $0.00^{*}$ \\
\hline \hline N225 to BSE 9.25 0.00* & KSE to KOSPI & 0.27 & 0.60 \\
\hline BSE to N225 0.60 0.43 & KOSPI to KSE & 24.7 & $0.00^{*}$ \\
\hline \hline SSE to BSE $11.20 .00^{*}$ & N225 to KOSPI & 4.57 & $0.03^{*}$ \\
\hline BSE to SSE 3.23 0.05* & KOSPI to N225 & 0.01 & 0.93 \\
\hline \hline KLSE to CSE 5.550 .01 & SSE to KOSPI & 10.5 & $0.00^{*}$ \\
\hline CSE to KLSE 0.440 .61 & KOSPI to SEE & 0.82 & 0.36 \\
\hline KOSPI to CSE 0.35 0.54 & N225 to KSE & 0.33 & 0.56 \\
\hline
\end{tabular}




\begin{tabular}{llcc}
\hline CSE to KOSPI 0.280 .59 & KSE to N225 & 1.30 & 0.25 \\
\hline \hline KSE to CSE 0.320 .56 & SSE to KSE & 7.63 & $0.00^{*}$ \\
\hline CSE to KSE 1.14014 & KSE to SSE & 0.48 & 0.48 \\
\hline \hline N225 to CSE 1.590 .20 & SSE to N225 & 0.39 & 0.53 \\
\hline CSE to N225 1.410 .06 & N225 to SSE & 5.98 & $0.01^{*}$ \\
\hline \hline SSE to CSE 1.340 .99 & SSE to CSE & 1.34 & 0.99 \\
\hline CSE to SSE 0.090 .73 & CSE to SSE & 0.09 & 0.73 \\
\hline
\end{tabular}

Notes: The table recaps the unidirectional and bidirectional causal relationship in the Asian developed and emerging stock market indices for the period of 17 years data from 2001-2017. This study found unidirectional associations and only one bidirectional association between the selected variables. $(*)$ indicates relationships in variables.

The stock market that causes the other is leading, and the follower is lagging the stock market. The research found unidirectional causal relationship from Malaysia to India, India to South Korea, India to Pakistan, Japan to India, China to India, Malaysia to Sri Lanka, Malaysia to South

Korea, Malaysia to China, South Korea to Pakistan, South Korea to China, Japan to South Korea, China to South Korea, Japan to China, and China to Pakistan. The research study further found bidirectional relationships between India and South Korea and India and China. The results of the Granger Causality tests clarify that Japan is the most developed stock market of the sample. The bidirectional causal relationship indicates that both stock markets affect each other. Both the stock markets are leading and lagging behind each other-the results from the Granger Causality test consistent with Variance Decomposition and Impulse Response Function (IRF).

\section{Variance Decomposition}

The research study employed Variance Decomposition to examine that how many variances in any stock market are happening in percentage by its advancement and how many clashes are occurring by other stock markets of the research study, Moon (2018), Jebaran (2014), Shezad et al. (2014). Tables 8 to 14 comprise the variance decomposition results of the time series variables under study. The India stock market indices result shows that 94 percent of variances in India are due to its improvements. Only 2.98 percent of conflicts are due to innovation in Malaysia. The variance decomposition of Sri Lankan Stock market indices illustrates that the foremost variances in Sri Lankan stock markets indices are due to its innovation which is 95.7 percent and in Indonesian indices, 99.3 percent of variances are carried by its own.

Table 8: Variance decomposition of BSE

\begin{tabular}{llllllll}
\hline Period BSE & CSE & KLSE & KOSPI & KSE & N225 & SSE \\
\hline 1 & 100.0 & 0.00 & 0.00 & 0.00 & 0.00 & 0.00 & 0.00 \\
\hline 2 & 94.37 & 0.07 & 2.83 & 0.35 & 0.33 & 0.47 & 1.14 \\
\hline 3 & 94.18 & 0.07 & 2.97 & 0.36 & 0.34 & 0.48 & 1.14 \\
\hline 4 & 94.17 & 0.07 & 2.97 & 0.36 & 0.35 & 0.49 & 1.14 \\
\hline 5 & 94.17 & 0.07 & 2.98 & 0.36 & 0.35 & 0.49 & 1.14 \\
\hline 6 & 94.17 & 0.07 & 2.98 & 0.36 & 0.35 & 0.49 & 1.14 \\
\hline 7 & 94.17 & 0.07 & 2.98 & 0.36 & 0.35 & 0.49 & 1.14 \\
\hline 8 & 94.17 & 0.07 & 2.98 & 0.36 & 0.35 & 0.49 & 1.14 \\
\hline 9 & 94.17 & 0.07 & 2.98 & 0.36 & 0.35 & 0.49 & 1.14 \\
\hline 10 & 94.17 & 0.07 & 2.98 & 0.36 & 0.35 & 0.49 & 1.14 \\
\hline
\end{tabular}

Notes: The table includes the variance decomposition of India stock market indices. The result demonstrates that $94 \%$ of variances in its stock price indices are brought by its own innovation and very little $2.98 \%$ by Malaysia.

Table 9: Summarizes Variance decomposition of CSE

\begin{tabular}{lcccccccc}
\hline \multicolumn{2}{l}{ Period CSE } & BSE & KLSE & JKSE & KOSPI & KSE & N225 & SSE \\
\hline 1 & 96.7 & 3.21 & 0.00 & 0.00 & 0.00 & 0.00 & 0.00 & 0.00 \\
\hline 2 & 95.8 & 3.21 & 0.70 & 0.03 & 0.03 & 0.04 & 0.06 & 0.02 \\
\hline 3 & 95.7 & 3.22 & 0.75 & 0.04 & 0.03 & 0.06 & 0.07 & 0.03 \\
\hline 4 & 95.7 & 3.22 & 0.76 & 0.04 & 0.03 & 0.06 & 0.07 & 0.03 \\
\hline 5 & 95.7 & 3.22 & 0.76 & 0.04 & 0.03 & 0.06 & 0.07 & 0.03 \\
\hline
\end{tabular}


https://doi.org/10.18510/hssr.2021.93116

\begin{tabular}{lllllllll}
\hline 6 & 95.7 & 3.22 & 0.76 & 0.04 & 0.03 & 0.06 & 0.07 & 0.03 \\
\hline 7 & 95.7 & 3.22 & 0.76 & 0.04 & 0.03 & 0.06 & 0.07 & 0.03 \\
\hline 8 & 95.7 & 3.22 & 0.76 & 0.04 & 0.03 & 0.06 & 0.07 & 0.03 \\
\hline 9 & 95.7 & 3.22 & 0.76 & 0.04 & 0.03 & 0.06 & 0.07 & 0.03 \\
\hline 10 & 95.7 & 3.22 & 0.76 & 0.04 & 0.03 & 0.06 & 0.07 & 0.03 \\
\hline
\end{tabular}

Notes: The table includes the variance decomposition of Sri Lankan stock market indices. The result demonstrates that $95.7 \%$ of variances in its stock price indices are carried out by its advancement and $2.3 \%$ by India.

Table 10: Summarizes Variance decomposition of KLSE

\begin{tabular}{llllllll}
\hline \multicolumn{2}{l}{ Period KLSE } & BSE & CSE & KOSPI & KSE & N225 & SSE \\
\hline 1 & 99.5 & 0.24 & 0.21 & 0.00 & 0.00 & 0.00 & 0.00 \\
\hline 2 & 97.5 & 0.35 & 0.23 & 0.14 & 0.16 & 0.58 & 0.61 \\
\hline 3 & 97.5 & 0.36 & 0.23 & 0.15 & 0.17 & 0.58 & 0.61 \\
\hline 4 & 97.5 & 0.36 & 0.23 & 0.15 & 0.18 & 0.58 & 0.61 \\
\hline 5 & 97.5 & 0.36 & 0.23 & 0.15 & 0.18 & 0.58 & 0.61 \\
\hline 6 & 97.5 & 0.36 & 0.23 & 0.15 & 0.18 & 0.58 & 0.61 \\
\hline 7 & 97.5 & 0.36 & 0.23 & 0.15 & 0.18 & 0.58 & 0.61 \\
\hline 8 & 97.5 & 0.36 & 0.23 & 0.15 & 0.18 & 0.58 & 0.61 \\
\hline 9 & 97.5 & 0.36 & 0.23 & 0.15 & 0.18 & 0.58 & 0.61 \\
\hline 10 & 97.5 & 0.36 & 0.23 & 0.15 & 0.18 & 0.58 & 0.61 \\
\hline
\end{tabular}

Notes: The table comprises the variance decomposition of Malaysian stock market indices. The result demonstrates that $97.5 \%$ of variances in its stock price indices are carried out by its own advancement.

Table 11: Recapitulates Variance decomposition of KOSPI.

\begin{tabular}{llcccccc}
\hline \multicolumn{2}{l}{ Period KOSPI } & BSE & CSE & KLSE & KSE & N225 & SSE \\
\hline 1 & 72.3 & 27.4 & 0.00 & 0.00 & 0.00 & 0.00 & 0.00 \\
\hline 2 & 69.8 & 26.3 & 0.00 & 2.66 & 0.03 & 0.09 & 0.58 \\
\hline 3 & 69.8 & 26.3 & 0.00 & 2.70 & 0.04 & 0.11 & 0.58 \\
\hline 4 & 69.8 & 26.3 & 0.00 & 2.70 & 0.04 & 0.11 & 0.58 \\
\hline 5 & 69.8 & 26.3 & 0.00 & 2.70 & 0.04 & 0.11 & 0.58 \\
\hline 6 & 69.8 & 26.3 & 0.00 & 2.70 & 0.04 & 0.11 & 0.58 \\
\hline 7 & 69.8 & 26.3 & 0.00 & 2.70 & 0.04 & 0.11 & 0.58 \\
\hline 8 & 69.8 & 26.3 & 0.00 & 2.70 & 0.04 & 0.11 & 0.58 \\
\hline 9 & 69.8 & 26.3 & 0.00 & 2.70 & 0.04 & 0.11 & 0.58 \\
\hline 10 & 69.8 & 26.3 & 0.00 & 2.70 & 0.04 & 0.11 & 0.58 \\
\hline
\end{tabular}

Notes: The table includes the variance decomposition of South Korean stock market indices. The result exhibits that $69.8 \%$ of variances in stock price indices is brought by its own innovation and $26.9 \%$ is due to improvements in India.

Table 12: Summarizes Variance decomposition of KSE

\begin{tabular}{cccccccc}
\hline Period & KSE & BSE & CSE & KLSE & KOSPI & N225 & SSE \\
\hline 1 & 99.6 & 0.00 & 0.05 & 0.10 & 0.00 & 0.00 & 0.00 \\
\hline 2 & 96.4 & 0.93 & 0.14 & 0.10 & 2.04 & 0.06 & 0.07 \\
\hline 3 & 96.2 & 1.00 & 0.14 & 0.18 & 2.03 & 0.07 & 0.09 \\
\hline 4 & 96.2 & 1.00 & 0.14 & 0.19 & 2.04 & 0.07 & 0.09 \\
\hline 5 & 96.2 & 1.00 & 0.14 & 0.19 & 2.04 & 0.07 & 0.09 \\
\hline 6 & 96.2 & 1.00 & 0.14 & 0.19 & 2.04 & 0.07 & 0.09 \\
\hline 7 & 96.2 & 1.00 & 0.14 & 0.19 & 2.04 & 0.07 & 0.09 \\
\hline 8 & 96.2 & 1.00 & 0.14 & 0.19 & 2.04 & 0.07 & 0.09 \\
\hline 9 & 96.2 & 1.00 & 0.14 & 0.19 & 2.04 & 0.07 & 0.09 \\
\hline 10 & 96.2 & 1.00 & 0.14 & 0.19 & 2.04 & 0.07 & 0.09 \\
\hline
\end{tabular}


Notes: The table comprises the variance decomposition of Pakistani stock market indices. The result demonstrates that $96.2 \%$ of variances in stock price indices are carried by its innovation and $2.4 \%$ by South Korea.

Table 13: Summarizes the Variance decomposition of N225

\begin{tabular}{cccccccc}
\hline Period & N225 & BSE & CSE & KLSE & KOSPI & KSE & SSE \\
\hline 1 & 92.8 & 0.00 & 0.04 & 6.82 & 0.19 & 0.01 & 0.00 \\
\hline 2 & 91.5 & 0.06 & 0.62 & 7.13 & 0.20 & 0.18 & 0.06 \\
\hline 3 & 91.5 & 0.06 & 0.62 & 7.13 & 0.20 & 0.18 & 0.06 \\
\hline 4 & 91.5 & 0.07 & 0.62 & 7.13 & 0.20 & 0.18 & 0.06 \\
\hline 5 & 91.5 & 0.07 & 0.62 & 7.13 & 0.20 & 0.18 & 0.06 \\
\hline 6 & 91.5 & 0.07 & 0.62 & 7.13 & 0.20 & 0.18 & 0.06 \\
\hline 7 & 91.5 & 0.07 & 0.62 & 7.13 & 0.20 & 0.18 & 0.06 \\
\hline 8 & 91.5 & 0.07 & 0.62 & 7.13 & 0.20 & 0.18 & 0.06 \\
\hline 9 & 91.5 & 0.07 & 0.62 & 7.13 & 0.20 & 0.18 & 0.06 \\
\hline 10 & 91.5 & 0.07 & 0.62 & 7.13 & 0.20 & 0.18 & 0.06 \\
\hline
\end{tabular}

Notes: The table comprises the variance decomposition of Japanese stock market indices. The result determines that $91.5 \%$ of variances in stock price indices are carried by its innovation and $7.1 \%$ by Malaysia.

Table 14: Summarizes the Variance decomposition of SSE

\begin{tabular}{cccccccc}
\hline Period & SSE & BSE & CSE & KLSE & KOSPI & KSE & N225 \\
\hline 1 & 49.3 & 35.7 & 0.28 & 0.00 & 14.3 & 0.05 & 0.04 \\
\hline 2 & 46.9 & 34.1 & 0.32 & 3.96 & 14.1 & 0.10 & 0.15 \\
\hline 3 & 46.9 & 34.0 & 0.32 & 3.99 & 14.1 & 0.12 & 0.18 \\
\hline 4 & 46.9 & 34.0 & 0.32 & 3.99 & 14.1 & 0.12 & 0.18 \\
\hline 5 & 46.9 & 34.0 & 0.32 & 3.99 & 14.1 & 0.12 & 0.18 \\
\hline 6 & 46.9 & 34.0 & 0.32 & 3.99 & 14.1 & 0.12 & 0.18 \\
\hline 7 & 46.9 & 34.0 & 0.32 & 3.99 & 14.1 & 0.12 & 0.18 \\
\hline 8 & 46.9 & 34.0 & 0.32 & 3.99 & 14.1 & 0.12 & 0.18 \\
\hline 9 & 46.9 & 34.0 & 0.32 & 3.99 & 14.1 & 0.12 & 0.18 \\
\hline 10 & 46.9 & 34.0 & 0.32 & 3.99 & 14.1 & 0.12 & 0.18 \\
\hline
\end{tabular}

Notes: The table includes the variance decomposition of Chinese stock market indices. The result validates that $48 \%$ of variances in stock price indices are approved by its own innovation, 32\% by India, and 8.9\% by South Korea.

Innovation: In the case of Malaysia, 97.5 percent of variances in its stock price indices is carried out by its own advancement. Further the results from the Variance Decomposition demonstrate that in the case of South Korea 69.8 percent of variances in stock price indices are brought by its own innovation and 26.9 percent is due to improvements in India. The results of the Pakistani Stock market show that 97 percent of variances in stock price indices are carried by its own innovation. Further, the results determine that in the Japan 91.5 percent of variances in stock price indices is carried by its own innovation and 7.1 percent by Malaysia. In the case of China, 48 percent of variances in stock price indices is approved by its own innovation, 32 percent by India, and 8.9 percent by South Korea. As from the results of the variance decomposition, it is cleared that almost all the variances in these stock markets are due to their own innovations, Moon (2001), Jebaran (2014), Shezad et al (2014). Variance Decomposition declared the Indonesian stock market as exogenous in Asian developed and emerging stock markets of the sample, which is consistent with Granger causality and IRF.

\section{Impulse Response Function (IRF)}

The Impulse Response function (IRF) is employed to forecast that how much the shocks in one country are affecting the other country. The figure 1 to 7 summarizes the IRF of the Asian developed and emerging stock markets. The $\mathrm{x}$-axis in the figures indicates the data period up to ten periods, so this research study is analyzing weekly data. Here the Impulse Response Function can forecast the shocks occurring in one country up to ten weeks in the other country. The y-axis indicates the percentage change that occurred from shocks in one country to the other country. Figure 1 charts the response of KSE to the stock markets indices of the study. The response of KSE to KSE indicates that is highly positive during the first two weeks then gradually decreased and comes to level in the third week then consistent up to ten weeks. Figure 2 shows the response of BSE to the other seven stock indices of the study. The response of BSE to BSE indicates that in the first week the response is highly positive, which is gradually decreased and in the third week, it is positive but consistent up to ten weeks. Figure 3 shows the response of CSE to the other stock market indices of the study. The 
response of CSE to CSE is highly positive in the first weeks then gradually decreased up to the fourth week and then consistent up to ten weeks. Figure 4 graphs the response of KLSE to the stock markets indices of the study. The response of KLSE to KLSE indicates that is highly positive during the first two weeks then gradually decreased and comes to a level in the fourth week which is consistent up to ten weeks. Figure 5 charts the response of SSE to the stock markets indices of the study. The response of SSE-to-SSE indicates that is highly positive during the first week then gradually decreased and becomes negative in the second week, again come to a level in the third week then consistent up to ten weeks. The response of SSE to N225 is positively the least increase in first two weeks then decreased and come to a level in the third week, which is consistent up to ten weeks. The response of SSE to CSE is positive in the first week, then negative in the second week again come to level in the third week and consistent up to ten weeks. Figure 6 charts the response of KOSPI to the stock markets indices of the study. The response of KOSPI to KOSPI indicates that is highly positive during the first week then gradually decreased and becomes negative in the second week, again come to a level in the third week then consistent up to ten weeks. Figure 7 graphs the response of N225 to the stock markets indices of the study. The response of N225 to N225 indicates that is highly positive during the first week, then becomes negative in the second week and in the third week again positive and consistent up to ten weeks.

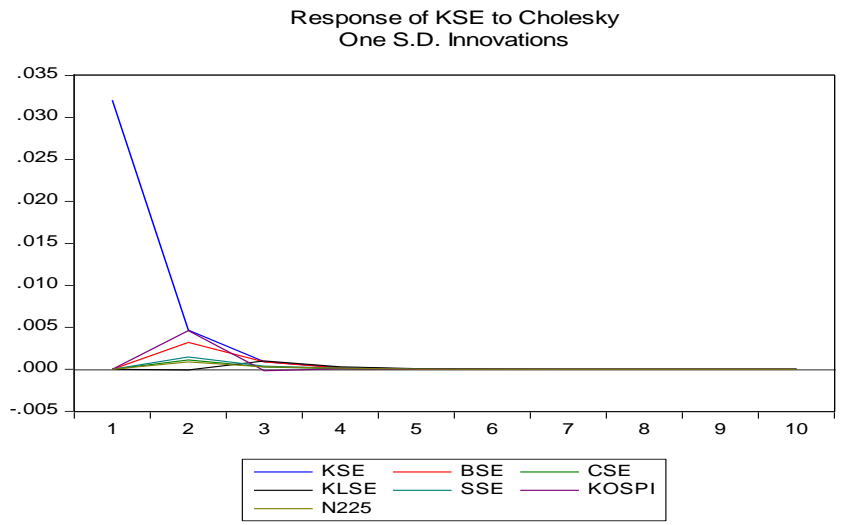

Figure 1: Response of KSE to Cholesky

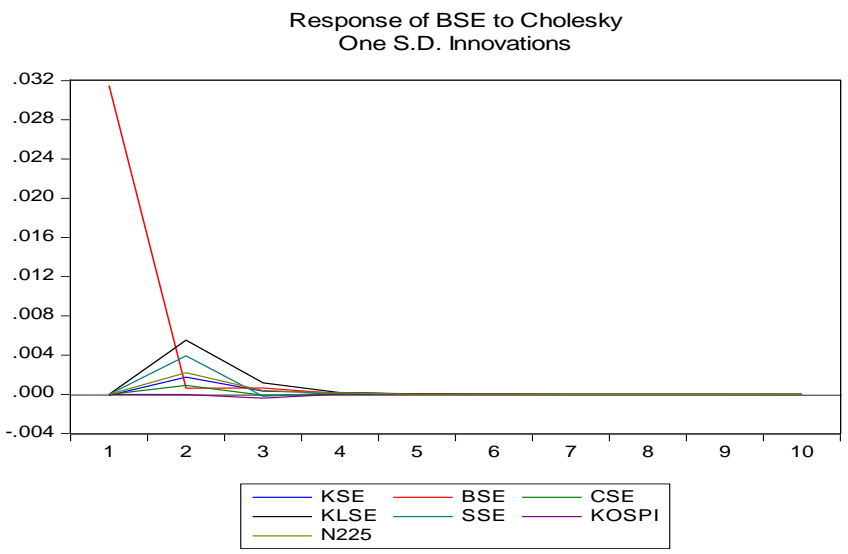

Figure 2: Response of BSE to Cholesky

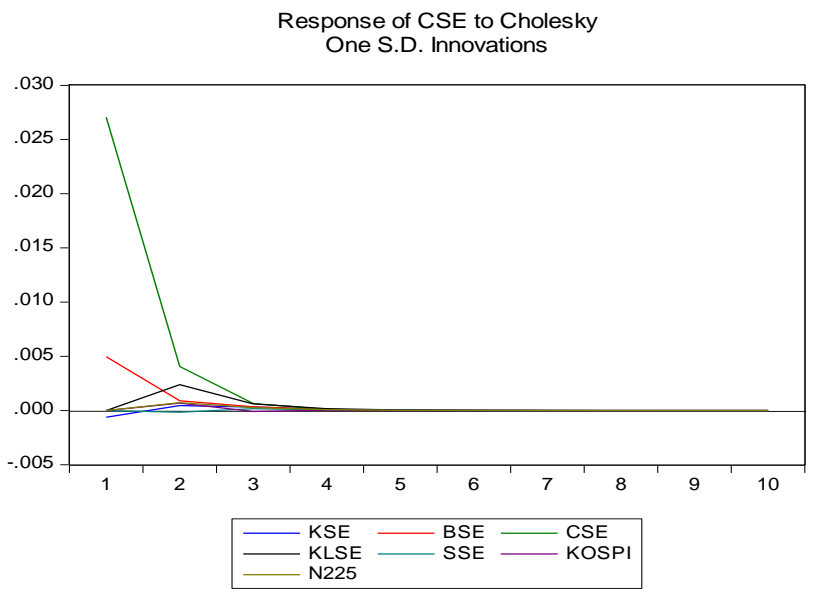

Figure 3: Response of CSE to Cholesky 
Humanities \& Social Sciences Reviews

elSSN: 2395-6518, Vol 9, No 3, 2021, pp 1175-1190

https://doi.org/10.18510/hssr.2021.93116

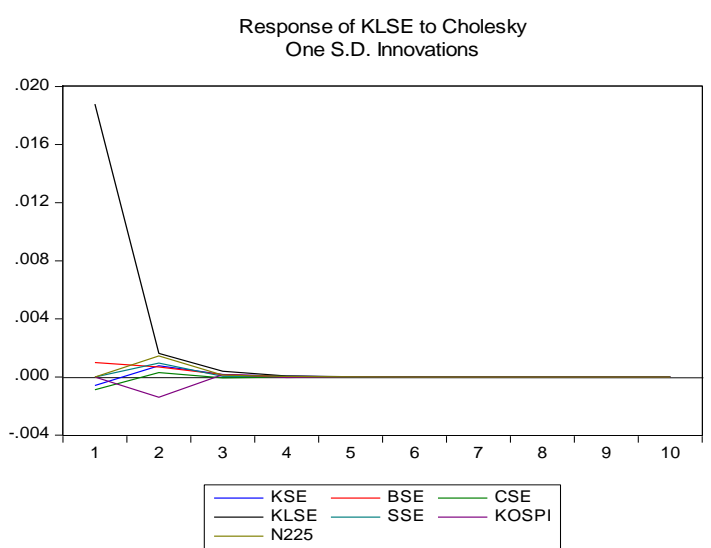

Figure 4: Response of KLSE to Cholesky

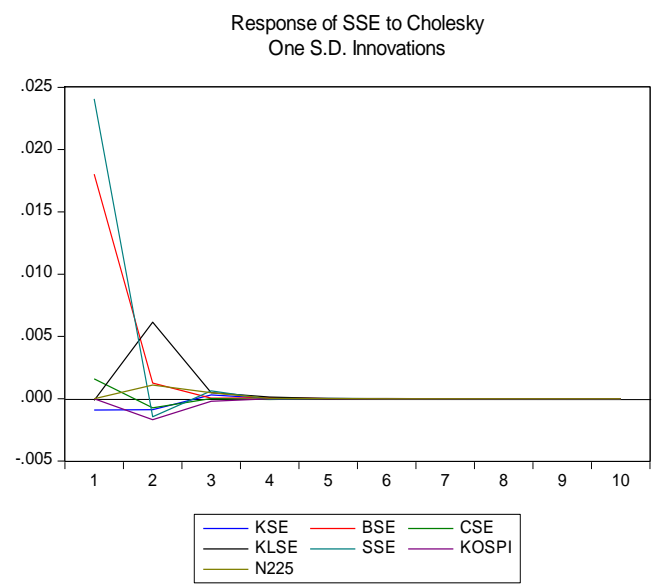

Figure 5: Response of SSE to Cholesky

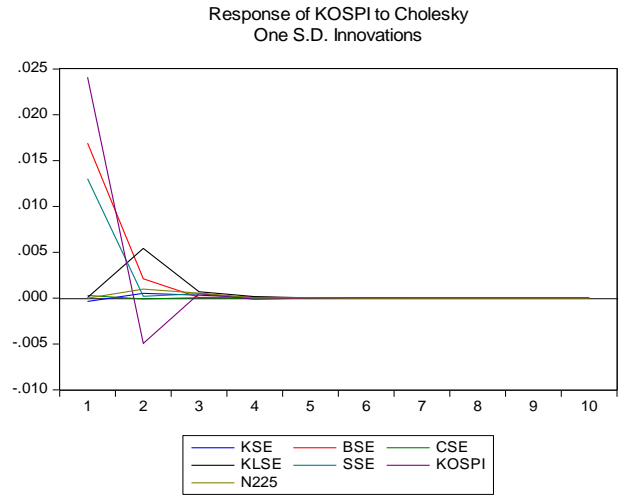

Figure 6: Response of BSE to Cholesky

Response of N225 to Cholesky One S.D. Innovations

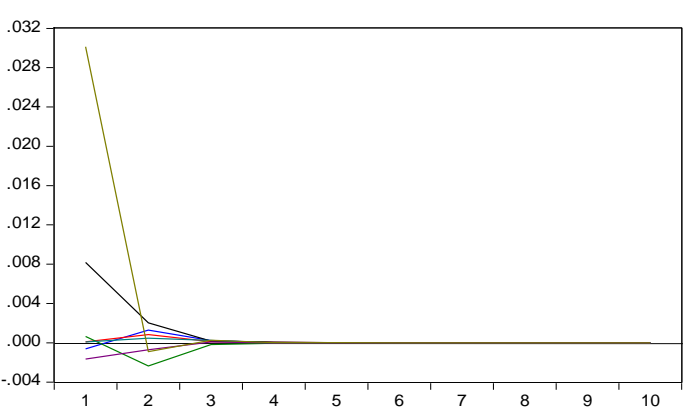

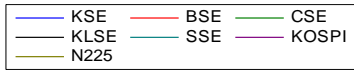

Figure 7: Response of N225 to Cholesky 


\section{CONCLUSION}

The study is based on time series secondary data of Asian Developed and Emerging stock market indices. The sample size is based on weekly data of stock market indices of Asian Developed and Emerging Markets which are Japan (Nikkei 225), South Korea (KOSPI), Pakistan (KSE 100), China (SSE Composite), Sri Lanka (ASPI), India (BSE 200) and Malaysia (KLSE composite) from 2001 to 2019. By employing the econometric tools this study achieved the objectives and find short-run, long-run and causal relationships among stock market indices under study. Therefore, the conclusion is the diversification benefits in these stock markets under investigation are limited for international investors, while short-run diversification benefits may exist.

\section{LIMITATION OF THE STUDY AND STUDY FORWARD}

The current study focused on seven Asian developed and emerging stock markets, while other researchers can investigate stock market integration in more than seven Asian developed and emerging markets. The sample period for the current study is 2001-2019, while another researcher can use different data periods for analysis. Further, another researcher can use different research tolls as using for different purposes likewise the Arch and Garch models are used to investigate risk during portfolio selection and to minimize risk in the portfolio diversification.

\section{AUTHOR'S CONTRIBUTIONS}

Sadiq Rehman: Data Analysis and its interpretation, Abstract and Conclusion writing, review of article after completion and correspondence with the journal.

Asif Ali Abro: Data Collection, working on Literature, writing references and after completion of research review the article.

Ahmed Raza UI Mustafa: Data Collection, working on Literature and after completion of research, its review.

Najeeb Ullah: Writing' Analysis and Interpretation', and 'Methodology.

Sanam Wagma Khattak: Writing' Literature Review' and 'Rationale of the Study', correspondence with the journal, and review after completing the article.

\section{REFERENCES}

1. Arshanapalli, B., \& Doukas, J. (1993). International stock market linkages: Evidence from the pre-and postOctober 1987 period. Journal of Banking \& Finance, 17(1), 193-208. ttps://doi.org/10.1016/03784266(93)90088-U

2. Bhunia, A., \& Das, A. (2017). Financial Market Integration: Empirical Evidence from India and Select South Asian Countries. Afro Asian Journal of Social Sciences, 3(3.1).

3. Canarella, G., Miller, S. M., \& Pollard, S. K. (2019). Dynamic stock market interactions between the Canadian, Mexican, and the United States markets: The NAFTA experience. Nova Science Publishers, Inc., 4th Quarter.

4. Chen, G. M., Firth, M., \& Rui, O. M. (2012). Stock market linkages: evidence from Latin America. Journal of Banking \& Finance, 26(6), 1113-1141. https://doi.org/10.1016/S0378-4266(01)00160-1

5. Chan, K. C., Gup, B. E., \& Pan, M. S. (1997). International stock market efficiency and integration: A study of eighteen nations. Journal of Business Finance \& Accounting, 24(6), 803-813. https://doi.org/10.1111/1468$\underline{5957.00134}$

6. Click, R.W. and Plummer, M.G. (2015). Stock Market Integration in ASEAN after the Asian Financial Crisis. Journal of Asian Economics, 16(1), 5-28

7. Chen, H., Lobo, B. J., \& Wong, W. K. (2016). Links between the Indian, U.S. and Chinese stock markets. National University of Singapore, Department of Economics, Working Paper, (0602).

8. Edison, H. J., Levine, R., Ricci, L., \& Sløk, T. (2012). International financial integration and economic growth. Journal of international money and finance, 21(6), 749-776.

9. Errunza, V., \& Losq, E. (1985). International asset pricing under mild segmentation: Theory and test. The Journal of Finance, 40(1), 105-124. https://doi.org/10.1111/j.1540-6261.1985.tb04939.x

10. Forbes, K. J., \& Rigobon, R. (2012). No contagion, only interdependence: measuring stock market comovements. The journal of finance, 57(5), 2223-2261. https://doi.org/10.1111/0022-1082.00494

11. Gilmore, C. G., \& McManus, G. M. (2012). International portfolio diversification: U.S. and Central European Equity Markets. Emerging Markets Review, 3(1), 69-83. https://doi.org/10.1016/S1566-0141(01)00031-0

12. Garrett, I., Hyde, S., \& Varas, J. (2014). The Interaction between Latin American Stock Markets and the U.S. University of Manchester, mimeo.

13. Gupta, N., \& Agarwal, V. (2011). Comparative study of distribution of Indian stock market with other Asian markets. International Journal of Enterprise Computing and Business Systems, 1(2), 1-20.

14. Gurcharan S Pritam S (2017) Chinese and Indian Stock Market Linkages with Developed Stock Markets, Asian Journal of Finance \& Accounting, 2(2), E2.

15. Harvie, C., \& Pahlavani, M. (2017). Sources of Economic Growth in South Korea. Korea and the World Economy, 8(2), 205-235. 
16. Iqbal, A., Khalid, N., \& Rafiq, S. (2017). Dynamic Interrelationship Among the Stock markets of India, Pakistan and United States. International Journal of Human and Social Sciences, 6(1), 31-37.

17. Jawadi, F., \& Arouri, M. E. H. (2018). Are American and French stock markets integrated? The International Journal of Business and Finance Research, 2(2), 107-116.

18. Jebran, K. (2014). Dynamic linkages between Asian countries stock markets: Evidence from Karachi Stock Exchange. Research Journal of Management Sciences, 3(5), 6-13.

19. Khan, S. N., \& Aslam, M. S. (2014). Co-integration of Karachi Stock Exchange with major South Asian Stock Exchanges. International Journal of Accounting and Financial Reporting,4(1), 106-117. https://doi.org/10.5296/ijafr.v4i1.5454

20. Khan, K. M., Khan, A. M., Ullah M., Usman, A., Farhat, S., (2020). Closing price determination; extent of manipulation and deterrent strategy formulation: a case of Pakistan Stock Exchange. Journal of Critical Reviews, 7(14), 2689-2705.

21. Lessard, D. R. (1973). International portfolio diversification: a multivariate analysis for a group of Latin American countries. The Journal of Finance, 28(3), 619-633. https://doi.org/10.1111/j.1540$\underline{6261.1973 . t b 01384 . x}$

22. Masih, A. M., \& Masih, R. (1999). Are Asian stock market fluctuations due mainly to intra-regional contagion effects? Evidence based on Asian emerging stock markets. Pacific-Basin Finance Journal, 7(3), 251-282. https://doi.org/10.1016/S0927-538X(99)00013-X

23. Meric, I., \& Meric, G. (1997). Comovements of European equity markets before and after the 1987 crash. Multinational Finance Journal, 1(2), 137-152. https://doi.org/10.17578/1-2-4

24. Moon, W. S. (2017). Currency crisis and stock market integration: A comparison of East Asian and European Experiences. Journal of International and Area Studies, 1, 41-56,

25. Palamalai, S., Kalaivani, M., \& Devakumar, C. (2013). Stock Market Linkages in Emerging Asia-Pacific Markets. SAGE Open, 3(4). https://doi.org/10.1177/2158244013514060

26. Rodriguez, F., \& Rodrik, D. (2016). Trade policy and economic growth: a skeptic's guide to the cross-national evidence. In NBER Macroeconomics Annual 2000, 15, 261-338. MIT Press. https://doi.org/10.1086/654419

27. Searat, Babar and Kashif (2011). Comovement Between Emerging and Developed Stock Markets: An Investigation Through Cointegration Analysis, World Applied Sciences Journal, 12(4), 395-403.

28. Shaikh, S., Channar, P., Shaikh, M., \&, Ullah, M., (2021). Financial constraints and listed sugar mills on Pakistan Stock Exchange. International Journal of Management, 12(3), 70-76.

29. Sulaiman D. Mohammad (2011). The Dynamic Linkages of Pakistani and Global Stock1 arkets: Evidence from Karachi Stock Exchange, 5(2), 233-242.

30. Tabak, B. M., \& Lima, E. J. A. (2013). Causality and cointegration in stock markets: the case of Latin America. Revista Brasileira de Economia de Empresas, 3(2), 1-28.

31. Ullah, M., Shaikh, M., Channar, P., \& Shaikh, S., (2021). Financial forecasting: an individual perspective. International Journal of Management, 12(3), 60-69.

32. Ullah, M., Malik., A.M., Zeb, A., Rehman, A. (2019). Mediating Role of Capital Structure between Corporate Governance and Risk. Journal of Managerial Sciences, 13(3), 47-56.

33. Wong, W. K., Agarwal, A., \& Du, J. (2014). Financial integration for India stock market: A fractional cointegration approach. Finance India, 18(4), 1581. 